\title{
Inhaled Antibiotic Therapy for Ventilator-Associated Tracheobronchitis and Ventilator-Associated Pneumonia: an Update
}

Tareq Abu-Salah · Rajiv Dhand

Received: February 14, 2011 / Published online: August 8, 2011

(c) The Author(s) 2011. This article is published with open access at Springerlink.com

\section{ABSTRACT}

Ventilator-associated pneumonia (VAP) remains a leading cause of morbidity and mortality in mechanically-ventilated patients in the Intensive Care Unit (ICU). Ventilator-associated tracheobronchitis (VAT) was previously believed to be an intermediate stage between colonization of the lower respiratory tract and VAP. More recent data, however, suggest that VAT may be a separate entity that increases morbidity and mortality, independently of the occurrence of VAP. Some, but not all, patients with VAT progress to develop VAP. Although inhaled antibiotics alone could be effective for the treatment of VAP, the current consensus of opinion favors their role as adjuncts to systemic antimicrobial therapy for VAP. Inhaled

Tareq Abu-Salah

Division of Pulmonary, Critical Care, and

Environmental Medicine, Department of Internal

Medicine, University of Missouri, Columbia, MO, USA

Rajiv Dhand $(\bowtie)$

Division of Pulmonary, Critical Care, and

Environmental Medicine, CE-407, DC043.00; 1 Hospital

Drive, University of Missouri, Columbia, MO 65212,

USA. Email: dhandr@health.missouri.edu antibiotics are increasingly employed for salvage therapy in patients with VAP due to multi-drug resistant Gram-negative bacteria. In contrast to VAP, VAT could be effectively treated with inhaled antibiotic therapy alone or in combination with systemic antimicrobials.

Keywords: aerosols; antibiotic resistance; antibiotics; colistin; Gram-negative pneumonia; levofloxacin; mechanical ventilation; nebulizer; tracheobronchitis

\section{INTRODUCTION}

Placement of an endotracheal tube increases the risk of developing pneumonia among mechanically-ventilated patients by $6-20$ fold compared to critically ill patients who are not intubated. ${ }^{1}$ Development of ventilatorassociated pneumonia (VAP) is undoubtedly associated with significant morbidity and mortality, particularly when it is associated with bacteremia due to multi-drug resistant (MDR) organisms. ${ }^{1-3}$ Inhaled antibiotics are useful adjuncts to systemic antibiotic therapy for reducing morbidity and mortality due to VAP, especially pneumonia caused by MDR pathogens. ${ }^{4,5}$ 
Ventilator-associated tracheobronchitis (VAT) was previously considered to be an intermediate step between oropharyngeal colonization and $\mathrm{VAP},{ }^{6}$ and specific antibiotic therapy was generally not recommended for its treatment. Recent findings indicate that VAT may not precede VAP and may be an independent entity that is associated with significant morbidity and mortality per $s e .^{7,8}$ The optimal antibiotic regimen(s) and route(s) of administration for treatment of VAT have not been established as yet. The purpose of the current review paper is to discuss the terminology of VAT and VAP, explain the rationale for using inhaled antibiotics in patients with VAT or VAP, and describe possible advantages and disadvantages of combining inhaled and systemic antibiotics for the treatment of these serious infections.

\section{METHODS}

An extensive search of the published literature including the terms 'inhaled antibiotics,' 'inhaled antimicrobials,' 'ventilatorassociated pneumonia,' 'ventilator-associated tracheobronchitis,' 'cystic fibrosis,' 'aerosols and mechanical ventilation,' 'bronchial circulation,' 'biofilms,' 'quorum sensing,' 'colistin,' 'tobramycin,' 'levofloxacin,' 'vibrating mesh nebulizers,' and 'PDDS device' was conducted. In addition, the bibliography of various retrieved articles was searched for any relevant papers.

\section{TERMINOLOGY}

Clinical features of infection, radiologic features, and microbiologic data are employed to distinguish airway colonization with bacteria from VAT or VAP (Tables 1 and 2).

\section{Airway Colonization}

Colonization of the lower airways is defined as the presence of a microorganism in the lower airways without clinical and radiological features of infection. A quantitative microbiological sample yields less than $10^{5} \mathrm{cfu} / \mathrm{mL}$ of microorganisms. ${ }^{9,10}$

\section{Ventilator-Associated Tracheobronchitis}

The Centers for Disease Control (CDC) defines VAT as a tracheobronchial infection that occurs at least 48 hours after intubation and meets the following

Table 1. Definitions of airway colonization, ventilator-associated tracheobronchitis, and ventilator-associated pneumonia clinical and radiologic criteria.

\begin{tabular}{|c|c|c|c|c|}
\hline & $\begin{array}{l}\text { Temperature }>38.3^{\circ} \mathrm{C} \\
\text { or }<36.0^{\circ} \mathrm{C}^{*}\end{array}$ & $\begin{array}{l}\text { Total leukocyte } \\
\text { count }^{*}>12,000 / \mathrm{mm}^{3} \\
\text { or }<4000 / \mathrm{mm}^{3}\end{array}$ & $\begin{array}{l}\text { Change in volume } \\
\text { or character } \\
\text { of respiratory } \\
\text { secretions* }^{*}\end{array}$ & $\begin{array}{l}\text { New or progressive } \\
\text { infiltrate on chest } \\
x \text {-rayt }\end{array}$ \\
\hline Airway colonization & - & - & \pm & - \\
\hline VAT & + & - & + & - \\
\hline VAP $\neq$ & + & + & + & + \\
\hline
\end{tabular}

${ }^{*}$ At least 2 of the 3 clinical criteria must be present for a diagnosis of VAP.

†The presence of a new infiltrate is the major clinical and radiological distinguishing feature between VAT and VAP.

However, infiltrates can be difficult to assess in mechanically-ventilated patients.

キOther clinical characteristics in patients with VAP may include altered mental status, increasing oxygen requirements, and auscultatory findings such as crackles or bronchial breath sounds.

$\mathrm{VAP}=$ ventilator-associated pneumonia; VAT=ventilator-associated tracheobronchitis. 
Table 2. Definitions of airway colonization, ventilator-associated tracheobronchitis, and ventilator-associated pneumonia microbiologic criteria.*

\begin{tabular}{llllll}
\hline & \multicolumn{2}{c}{$\begin{array}{l}\text { ETA semi- } \\
\text { quantitiative } \\
\text { culture }\end{array}$} & $\begin{array}{l}\text { ETA quantitative } \\
\text { culture }\end{array}$ & BAL & PSB \\
\hline $\begin{array}{l}\text { Airway } \\
\text { colonization }\end{array}$ & PMNL + & Low & $<10^{5} \mathrm{cfu} / \mathrm{ml}$ & $<10^{4} \mathrm{cfu} / \mathrm{ml}$ & $<10^{3} \mathrm{cfu} / \mathrm{ml}$ \\
VAT & $\begin{array}{l}\text { PMNL }+ \\
\text { bacteria }+\dagger\end{array}$ & Moderate to high & $>10^{5} \mathrm{cfu} / \mathrm{ml}$ & $<10^{4} \mathrm{cfu} / \mathrm{ml}$ & $<10^{3} \mathrm{cfu} / \mathrm{ml}$ \\
VAP & $\begin{array}{l}\text { PMNL }+>5 \% \\
\text { intracellular } \\
\text { bacteria }\end{array}$ & Moderate to high & $>10^{6} \mathrm{cfu} / \mathrm{ml}$ & $>10^{4} \mathrm{cfu} / \mathrm{ml}$ & $>10^{3} \mathrm{cfu} / \mathrm{ml}$ \\
& & & & \\
\hline
\end{tabular}

*Specimens obtained before antibiotic administration.

†Presence of bacteria on Gram-stain of ETA roughly correlates with $>1 \times 10^{5} \mathrm{cfu} / \mathrm{ml}$ of microorganisms. ${ }^{6}$

$\neq$ Diagnosis of VAP is considered to be microbiologically confirmed if significant growth is seen on PSB, BAL, or ETA cultures.

$\mathrm{BAL}=$ broncho-alveolar lavage $; \mathrm{ETA}=$ endotracheal aspirate $\mathrm{PMNL}=$ polymorphonuclear leukocytes; $\mathrm{PSB}=$ protected specimen brush; VAP=ventilator-associated pneumonia; VAT=ventilator-associated tracheobronchitis.

criteria: (1) patient has no clinical or radiological evidence of pneumonia; (2) two of the following signs and symptoms in the absence of other obvious source: fever (temperature $>38^{\circ} \mathrm{C}$ ), cough, new or increased sputum production, rhonchi, and wheezing; and (3) at least one of the following: a positive culture obtained by deep tracheal aspirate or bronchoscopy, and positive antigen test on respiratory secretions. ${ }^{11}$ Other investigators have based the diagnosis of VAT on similar criteria, but the cut-offs employed for positive $\left(\geq 10^{5}\right.$ or $10^{6} \mathrm{cfu} / \mathrm{ml}$ ) endotracheal aspirate cultures have differed. ${ }^{7-11}$ Thus, the major difference between VAT and VAP is the presence of a new or progressive infiltrate on chest $\mathrm{x}$-ray in the latter (Table 1). However, chest $\mathrm{x}$-ray findings in mechanically ventilated patients can be nonspecific, and many patients already have infiltrates at the time of admission to the Intensive Care Unit (ICU). Moreover, the quality of films obtained in the ICU could limit their sensitivity and specificity for detection of new or progressive infiltrates on chest $\mathrm{X}$-ray. Because of these limitations, there is considerable diagnostic overlap between patients with VAT or VAP.
VAT is thought to be the third most frequent ICU-acquired infection, after pneumonia and urinary tract infections. Depending on the definition employed and the ICU population studied, the incidence of VAT in various investigations varies from $1.4 \%$ to $10.6 \% .{ }^{7,8,12,13} \mathrm{~A}$ systematic review of the literature estimated that VAT affected $11.5 \%$ of ICU patients receiving mechanical ventilation for $>48$ hours. ${ }^{14}$

Gram-negative bacteria are the most frequent causes of VAT, accounting for $75 \%$ of the isolates. Pseudomonas aeruginosa, Staphylococcus aureus, and Acinetobacter baumannii are the most frequent organisms isolated. ${ }^{10}$ The infection is polymicrobial in $22 \%$ of cases. Organisms causing VAT are often MDR, and VAT is associated with prolongation of the duration of mechanical ventilation, increased ICU length of stay (LOS), and higher ICU mortality, compared to patients who do not develop VAT. ${ }^{7,8}$

\section{Ventilator-Associated Pneumonia}

Pneumonia which develops more than 48 hours after intubation is characterized as VAP. ${ }^{1,15}$ 
Radiologic features include the development of new or progressive infiltrate on chest $\mathrm{x}$-ray (Table 1). The diagnosis can be confirmed by positive blood or pleural fluid cultures similar to the tracheal secretions or histopathologic evidence of pneumonia, although these are positive in a minority of patients. ${ }^{11}$ A microbiologic confirmation also includes quantitative cultures with a bacterial count exceeding a diagnostic threshold of $1 \times 10^{3} \mathrm{cfu} / \mathrm{ml}$ in a protected brush specimen, $>1 \times 10^{4} \mathrm{cfu} / \mathrm{ml}$ in a broncho-alveolar lavage (BAL) fluid specimen, or $>1 \times 10^{6} \mathrm{cfu} / \mathrm{ml}$ in an endotracheal aspirate specimen (Table $2^{1,11}$ ).

VAP is undoubtedly one of the most important infections encountered in mechanically-ventilated patients. Enteric Gram-negative organisms are a more common cause of VAP than Gram-positive organisms, although the frequency of MDR Gram-negative bacteria and methicillin-resistant Staphylococcus aureus (MRSA) infection in ICUs is increasing. ${ }^{15-18}$

\section{Early-Onset VAP}

VAP occurring in the first 4 days of hospitalization is classified as early onset VAP, and is usually caused by antibiotic-sensitive bacteria. Potential pathogens in early onset-VAP in patients with no risk factors for MDR bacteria include Streptococcus pneumoniae, Haemophilus influenzae, Methicillin-sensitive Staphylococcus aureus, and Gram-negative bacteria such as Escherichia coli, Klebsiella pneumoniae, Enterobacter species, Proteus species, and Serratia marcescens. ${ }^{15-18}$

\section{Late-Onset VAP}

Pneumonia developing $\geq 5$ days after hospitalization is usually due to MDR pathogens, and is associated with increased mortality and morbidity. ${ }^{15-18}$ Early-onset VAP patients who previously received antibiotics or were hospitalized within 90 days of their current admission are treated as late-onset VAP. ${ }^{1,19}$ Other risk factors for MDR pathogens include residence in a nursing home, chronic dialysis, home infusion therapy, and contact with family members harboring MDR pathogens. ${ }^{1,20}$ Potential pathogens in late-onset VAP or in patients with risk factors for MDR pathogens include Pseudomonas aeruginosa, Acinetobacter species, Klebsiella pneumoniae (ESBL strain), MRSA, and Legionella pneumophila. ${ }^{16,17}$ The infection is polymicrobial in up to $40 \%$ of patients with VAP. ${ }^{15-18}$

\section{THE INTER-RELATIONSHIP BETWEEN VAT AND VAP}

VAT and VAP share common pathogenetic mechanisms; however, opinions differ about their inter-relationship. According to one view, development of VAT is an intermediate step in the continuum from oropharyngeal colonization with bacteria to eventual occurrence of VAP. ${ }^{6}$ In the other view, VAT is considered a separate clinical entity from VAP. ${ }^{7,8}$ The former view is supported by the results of surveillance cultures utilizing serial endotracheal aspirate specimens to evaluate the relationship between colonization and infection. ${ }^{21-24}$ The pathogen in most instances of VAP was present in previous endotracheal aspirates before the development of infection, ${ }^{21}$ and weekly surveillance endotracheal aspirate cultures may be helpful in detecting VAP due to MDR pathogens. ${ }^{22}$ Increasing numbers of lower respiratory tract pathogens have been shown to predict increased virulence and increased inflammation. ${ }^{6}$ In addition, post-mortem studies have shown a progression from bronchitis to pneumonia in mechanically ventilated ICU patients. ${ }^{25}$ Proponents of this view of progression from VAT to VAP recommend frequent microbiological monitoring of endotracheal 
aspirates and treatment for VAT when clinical and quantitative culture requirements are met. ${ }^{6}$

Recently, a one-year long prospective cohort study evaluated the characteristics of VAT in patients admitted to a University Hospital. ${ }^{8}$ ICU patients were clinically monitored on a daily basis for development of VAT or VAP, and respiratory cultures obtained when infection was suspected. Interestingly, the median onset of VAT was 7.5 days after intubation compared with 5 days for VAP, ie, onset of VAT occurred later than onset of VAP. Among 28 patients with VAT, nine patients progressed to VAP despite appropriate antibiotic therapy. ICU and hospital LOS, duration of mechanical ventilation, and hospital mortality were similar between patients with VAT and VAP. ${ }^{8}$ Previously, Nseir and colleagues also reported that the median time for development of VAT after initiation of mechanical ventilation was 10 days in surgical patients and 11 days in medical patients. ${ }^{7}$ The delayed onset of VAT compared with VAP suggests that VAT is an independent entity that is associated with significant morbidity, a view endorsed by the recent American Thoracic Society (ATS)/Infectious Diseases Society of America (IDSA) guidelines. ${ }^{1}$

\section{RATIONALE FOR INHALED ANTIBIOTIC THERAPY}

Successful treatment of respiratory tract infections requires adequate antimicrobial concentrations for sufficient duration at the site of infection. To be effective in the lung, antibiotics must penetrate in adequate concentrations into bronchial tissues, pulmonary parenchyma, the extracellular lining fluid (ELF), intraluminal secretions in the airways (sputum), and intraluminal inflammatory cells. ${ }^{26}$ The presence of microorganisms within the airway lumen propagates an inflammatory response within the airways that could damage the airway wall and worsen airway obstruction. ${ }^{27}$ Intraluminal bacteria within airways could also be a source for subsequent development of pneumonia and bacteremia.

Antibiotic inhalation achieves very high local drug concentrations within the lung compared to systemic administration of the same agent. Palmer and colleagues studied the concentrations of aerosolized antibiotics in sputum. ${ }^{28,29}$ The aerosolized antimicrobial agents achieved 200-fold greater concentration in the respiratory secretions than levels achieved in the blood. Compared to systemic therapy with the same drugs, inhalation therapy achieved much higher sputum concentrations with potentially lower systemic toxicity. ${ }^{28,29}$ Moreover, in patients with VAT, aerosolized antibiotics reduced the volume of purulent tracheal secretions without increasing the rate of microbial resistance. ${ }^{28}$

\section{Antibiotic Penetration via Bronchial Versus Pulmonary Circulation}

After systemic administration, antibiotic concentrations achieved in the ELF depend on the penetration across the pulmonary vasculature, which has a nonfenestrated endothelium. ${ }^{30}$ Some lipophilic agents, such as aminoglycosides, beta-lactams, and carbapenems, penetrate effectively into the ELF regardless of the presence of inflammation, and they achieve adequate antibiotic concentrations in respiratory secretions. ${ }^{31}$ In contrast, nonlipophilic agents, including quinolones, newer macrolides, tetracyclines, and clindamycin, depend on the presence of inflammation for adequate penetration. ${ }^{31}$ Moreover, many tight junctions in the alveolar epithelium make it relatively impermeable to drugs. In contrast, drug penetration from the bronchial circulation is facilitated by the 
presence of a fenestrated endothelium, ${ }^{32}$ and penetration is further enhanced by the presence of inflammation. ${ }^{26}$ After systemic administration, transport of antibiotics across the bronchial epithelium is also limited by tight junctions so that intraluminal antibiotic concentrations tend to be much lower than serum levels. ${ }^{33}$ Thus, there is limited antibiotic penetration into the ELF, airway lumen, and intraluminal secretions after systemic antibiotic administration. ${ }^{34-36}$ Furthermore, inhibitory factors in sputum ${ }^{34,35}$ could prevent eradication of organisms unless high antibiotic concentrations are achieved within sputum.

Inhaled antibiotics, on the other hand, achieve high concentrations in sputum, are mainly absorbed via the bronchial epithelium, and are rapidly distributed by a rich network of sub-mucosal capillaries to other areas of the lung, including the lung parenchyma. ${ }^{37}$ After inhalation, uptake through the bronchial mucosa should lead to significantly higher antibiotic concentrations at various sites in the lung, including the bronchial and pulmonary tissues. Thus, a two-pronged attack by combining systemically administered and inhaled antibiotics may be more effective in achieving uniformly high antibiotic levels in various lung compartments than those achieved by systemic antibiotics alone.

\section{Optimizing Antibiotic Levels in the Lung}

Inhaled antibiotics undoubtedly achieve high local concentrations within the lung, however to be effective the drugs need to diffuse through sputum and enhance bacterial killing. In patients with cystic fibrosis (CF), aerosolization of gentamicin achieved higher levels and more central aerosol deposition in the lung in patients with lower forced expiratory volume in one second $\left(\mathrm{FEV}_{1}\right){ }^{38}$ The concentrations of drug achieved in bronchial secretions of patients with CF directly correlate with clinical efficacy of antimicrobial treatment, ${ }^{39}$ and high concentrations of tobramycin have been reported in lung tissues after nebulization, while maintaining serum levels at very low levels. ${ }^{40}$

Several investigators employed methods to optimize drug delivery to the lower respiratory tract of mechanically-ventilated patients. ${ }^{41,42}$ O'Doherty and colleagues described wide variability in the efficiency of nebulized drug delivery to mechanically-ventilated patients depending on the dose, volume of fill, and the type of nebulizer employed. ${ }^{43}$ The efficiency of drug delivery could be enhanced several-fold by employing specialty jet nebulizers that produce an aerosol with a high fine-particle fraction, and by optimizing ventilator settings and turning off humidification in the ventilator circuit. ${ }^{29,44-46}$ With optimal methods of drug delivery, Palmer and colleagues ${ }^{47}$ consistently achieved antibiotic concentrations in tracheal aspirates that were 20- to 100-fold higher than the in-vitro Minimum Inhibitory Concentrations (MICs) of the organisms being treated. Newer generation nebulizers have further improved the efficiency of drug delivery. ${ }^{48}$ A newer generation nebulizer (Aeroneb Pro ${ }^{\circledR}$, Aerogen, Galway, Ireland) with a high efficiency of drug delivery ${ }^{49}$ was able to achieve high amikacin concentrations in lung tissues. ${ }^{50}$ The next generation Pulmonary Drug Delivery System (PDDS) ${ }^{51}$ has an even higher efficiency of delivering antibiotics; in mechanically-ventilated patients with VAP, it provided amikacin concentrations in ELF that were higher than the MIC for Gram-negative microorganisms while maintaining serum concentrations below nephrotoxic levels. ${ }^{52}$

In contrast to Gram-negative infections, only a few investigators have examined the effect of inhaled vancomycin for Gram-positive infections. ${ }^{28,53}$ Similarly to aminoglycosides, 
sputum concentrations of aerosolized vancomycin in mechanically-ventilated patients were 20 -fold higher compared to those achieved after intravenous administration, ${ }^{53}$ and use of aerosolized vancomycin enhanced clinical and microbiological outcomes of treatment. $^{28}$

In patients with $\mathrm{CF}$, inhaled levofloxacin achieves high concentrations within sputum, ${ }^{54}$ retains its bactericidal effects in the presence of sputum, and achieves rapid bacterial killing within 30 minutes. ${ }^{55}$ Moreover, levofloxacin had greater bactericidal activity against Pseudomonas aeruginosa isolates from CF patients as compared to tobramycin or amikacin. ${ }^{56}$ However, to the best of our knowledge, there is as yet no published clinical experience with inhaled levofloxacin in patients with VAT or VAP.

\section{Biofilm Formation and Quorum Sensing}

Formation of a biofilm on the inner surface of the endotracheal tube is thought to be an important factor in the development of VAP. ${ }^{57,58}$ The presence of a biofilm reduces the intraluminal diameter of endotracheal tubes, ${ }^{59}$ hinders the ability to cough up bacteria and secretions from the lower airways, and increases the need for tracheobronchial suctioning. Planktonic forms displaced from the biofilm by suction catheters or by the shearing action of inspiratory airflow during positive pressure ventilation have the potential to cause pneumonia. ${ }^{57,60}$ Several common organisms causing VAP, such as Pseudomonas aeruginosa, MRSA, Acinetobacter baumannii, Klebsiella pneumoniae, and Enterobacter cloacae are capable of forming biofilms. Within the biofilm, these bacteria grow slowly in layers embedded within a glycocalyx ${ }^{57,60-62}$ that reduces the rate of antibiotic diffusion into bacterial cells, ${ }^{63}$ makes them resistant to antibiotic killing, and promotes emergence of resistant phenotypes.

At a high bacterial density, the phenomenon of "quorum sensing" (QS) facilitates production of virulence factors and further promotes biofilm formation. ${ }^{58,64} \mathrm{QS}$ provides a mechanism for bacteria to sense their environment and coordinate expression of various genes within the entire bacterial population. ${ }^{65}$ QS also controls synthesis and secretion of a number of virulence factors. ${ }^{66,67}$

Pseudomonas aeruginosa possesses two distinct but interacting QS systems, Las and rhl, with the former controlling the latter system. ${ }^{68}$ Most strains of Pseudomonas aeruginosa initially colonizing intubated patients are QS-proficient. ${ }^{69}$ In critically ill patients, Le Berre and coworkers ${ }^{66}$ showed that most Pseudomonas aeruginosa strains associated with VAP had increased expression of elastase and pyocyanin. However, these studies were conducted in in vitro conditions, which may differ considerably from conditions in vivo, where the microenvironment in which Pseudomonas aeruginosa grows may modify the phenotypic characteristics of the strains.

Favre-Bonte and colleagues ${ }^{64}$ found that autoinducers (AI) are produced during colonization of intubated patients with Pseudomonas aeruginosa. However, the precise AI produced differed between isolates obtained from intubation devices versus those obtained concurrently from tracheal aspirates. QS inhibition could affect isolates growing inside the biofilm in intubation devices differently from those residing in the lungs. They concluded that isolates from tracheal aspirates produced significantly more elastase but less biofilm, and had marginally reduced adhesion capacity than isolates from the intubation devices. ${ }^{64}$

The importance of QS for pathogenesis of VAP is supported by the observations of Kohler and colleagues. ${ }^{70}$ This study found that most 
mechanically-ventilated patients were initially colonized with QS-deficient Pseudomonas aeruginosa isolates, but those who were initially colonized with QS-proficient isolates had a higher incidence of VAP, especially those colonized with strains of Pseudomonas aeruginosa that produced high levels of rhamnolipids, a QS-dependent virulence factor. Moreover, only those patients who developed VAP showed evidence of in vivo QS gene induction. ${ }^{70}$ Antagonists that could inhibit intercellular communication in Pseudomonas aeruginosa biofilms have been suggested as new preventive/ therapeutic strategies for Pseudomonas aeruginosa infections. $^{71}$

Antibiotic treatment for increased numbers of bacteria in endotracheal aspirates, even in the absence of clinical signs of infection, could have beneficial effects by reducing the production of virulence factors. In mechanically-ventilated patients with newly acquired Pseudomonas aeruginosa infection, a high microorganism burden was associated with secretion of the type III secretion facilitator protein (PcrV), and the risk of death was significantly higher in these patients despite antibiotic treatment. ${ }^{72}$ Likewise, Matsushima and colleagues administered antibiotics according to ATS/IDSA guidelines to 133 patients based on positive Gram stains of endotracheal aspirates and compared the outcomes to a prior control group of 128 patients who had not received antibiotic therapy. ${ }^{73}$ Such pre-emptive antibiotic therapy, regardless of clinical and radiological evidence of VAP, reduced the incidence of subsequent VAP without increasing overall antibiotic use; the frequency of developing Acute Respiratory Distress Syndrome (ARDS) and VAP-associated mortality rate were also decreased. ${ }^{73}$ Although this study was not randomized, these provocative observations highlight the need for prospective randomized controlled trials (RCT) to further explore the role of earlier intervention with antibiotics in critically ill patients with a high bacterial burden.

After systemic administration, the low antibiotic concentrations achieved within the airway lumen have the potential to induce biofilm formation. ${ }^{74}$ In contrast, inhaled antibiotics achieve high local concentrations that could suppress biofilm formation, inhibit bacterial growth within the biofilm, ${ }^{75}$ decrease the potential for QS, and reduce the emergence of MDR bacteria. Thus, the role of inhaled antibiotics in potentially reducing or disrupting biofilm formation and decreasing the emergence of MDR organisms requires further investigation.

In the context of biofilm formation and development of VAP, it is interesting to note that the use of silver-coated endotracheal tubes, which inhibit biofilm formation, reduced the incidence of VAP, and delayed time to VAP occurrence. ${ }^{76}$ Recently, gardine (a combination of two antiseptics, namely brilliant green and chlorhexidine) or gendine (a combination of gentian violet and chlorhexidine)-coated endotracheal tubes were found to be superior to silver coated endotracheal tubes in preventing biofilm formation by MRSA, Pseudomonas aeruginosa, Acinetobacter baumannii, Klebsiella pneumoniae, Enterobacter cloacae, and Candida albicans. ${ }^{77}$ Future RCT are needed to evaluate the effects of gardine and gendine-coated endotracheal tubes on prevention of VAP and ICU mortality.

\section{DRUGS EMPLOYED FOR INHALED ANTIBIOTIC THERAPY}

In the past, intravenous formulations of antibiotics that contained preservatives, such as phenol and bisulfites, were used for inhalation. Ideally, solutions employed for inhalation must be sterile, nonpyrogenic, and 
preservative free. They should also be $\mathrm{pH}$, osmolality, and salinity adjusted to minimize airway irritation. ${ }^{4}$ Several antibiotics, including tobramycin, colistin, polymyxin B, gentamicin, amikacin, ceftazidime, vancomycin, aztreonam, amphotericin $\mathrm{B}$, pentamidine, ribavirin, and zanamavir have been administered by inhalation. ${ }^{78}$ In mechanically-ventilated patients, inhaled tobramycin and colistin are often employed as these two antibiotics have been specifically formulated in solutions for aerosolized delivery. ${ }^{4,78}$ Amikacin by inhalation (NKTR061) is in clinical trials for treatment of Gram-negative VAP. ${ }^{52}$ The US Food and Drug Administration (FDA) has recently approved an inhaled liposomal nanoparticle formulation of amikacin (Arikace $^{\circledR}$, Transave Inhalation Biotherapeutics, Monmouth Junction, NJ) and inhaled aztreonam (Cayston ${ }^{\circledR}$, Gilead Sciences, Foster City, CA) for treatment of Pseudomonas aeruginosa infection in patients with CF. Likewise, the use of inhaled levofloxacin has shown promising results in CF patients. ${ }^{79}$

\section{TREATMENT OF VAT WITH INHALED ANTIMICROBIALS}

Inhaled antibiotic therapy may prevent progression from VAT to VAP in some patients. In a randomized, blinded, placebo-controlled trial, 43 patients were randomized to receive aerosolized antibiotics versus placebo (saline) for 14 days. ${ }^{28}$ Compared to the placebo group, the use of inhaled and systemic antibiotics was associated with lower rates of VAP, faster weaning from the ventilator, reduced number of MDR pathogens, and lesser use of systemic antibiotics. ${ }^{28}$ The lack of quantitative cultures of endotracheal aspirates, and the presence of prior VAP in a high number of patients, were significant limitations of this study.
A consensus regarding treatment of VAT with antibiotics has remained elusive. Some experts recommend treatment, especially for those patients with VAT who have underlying disease or exhibit weaning difficulties, ${ }^{10,28,80}$ whereas others argue in favor of treating VAT only when there is infection with MDR organisms in an attempt to reduce morbidity and prevent progression to VAP. ${ }^{81-83}$

Prospective observational case-control studies in mechanically-ventilated patients with chronic obstructive pulmonary disease (COPD), ${ }^{84}$ and those without chronic respiratory disease, ${ }^{85}$ found that patients with VAT had longer durations of mechanical ventilation and ICU stay, but occurrence of VAT did not impact mortality rates. A later, prospective, randomized, controlled multicenter study in patients with $\mathrm{VAT}^{86}$ found that the group who received antibiotics had more ventilatorfree days (median 12 days versus 2), lower subsequent development of VAP (13\% versus $47 \%$ ), and lower ICU mortality rates (18\% versus $47 \%$ ), but no differences were observed in duration of mechanical ventilation or ICU LOS compared to patients who did not receive antibiotics. ${ }^{86}$ However, this study was not blinded and antibiotic therapy was not standardized. Moreover, because the trial had to be stopped early there were a smaller total number of patients than planned and there was an imbalance in the number of patients assigned to the antibiotic and control groups. ${ }^{86}$ Nevertheless, these findings stress the need for further studies to investigate the efficacy of appropriate antibiotics in patients with VAT.

A meta-analysis of published studies ${ }^{14}$ found that use of antimicrobial agents (systemic with or without inhaled antibiotics) for VAT reduced the frequency of subsequent episodes of pneumonia and increased ventilator-free days. However, antibiotic usage for VAT did not 
lower mortality, shorten ICU LOS, or reduce duration of mechanical ventilation compared to patients receiving placebo or no treatment. ${ }^{14}$ The lack of convincing evidence to support the use of inhaled antibiotics has led some experts to caution against their use for the treatment of VAT on the grounds that inhaled antibiotics are ineffective and their routine use could promote the emergence of resistant bacteria. ${ }^{87}$ Clearly, more data are needed to establish the appropriate role of inhaled antibiotics for treatment of VAT.

\section{TREATMENT OF VAP WITH INHALED ANTIBIOTICS}

Treatment of VAP depends on the onset of VAP and the risk factors for MDR pathogens. The choice of antibiotics should be modified based on knowledge of the predominant pathogens and the local antibiotic susceptibilities which are variable among different clinical institutions. ${ }^{88}$ Inappropriate selection of initial antibiotics is associated with increasing antimicrobial resistance ${ }^{89}$ and excess hospital mortality. ${ }^{90,91}$

\section{Treatment of VAP with Systemic and Inhaled Antibiotics}

Recommended antibiotics in early-onset VAP with no risk factors for MDR pathogens include ceftriaxone, fluoroquinolones, ampicillin/ sulbactam, or ertapenem. Combination antibiotic therapy is indicated for late-onset VAP and patients at high risk for MDR pathogens. This includes antipseudomonal cephalosporins (cefepime, ceftazidime), antipseudomonal carbapenem (imipenem, meropenem, or doripenem), or beta-lactam/beta-lactamase inhibitor combination (piperacillin/tazobactam or ticarcillin/clavulanate), or a monobactam (aztreonam) plus an antipseudomonal fluoroquinolone (ciprofloxacin or levofloxacin), or aminoglycosides (amikacin, gentamicin, or tobramycin) plus linezolid, or vancomycin if there is suspicion of MRSA infection. ${ }^{1}$ Once the results of respiratory tract cultures are available, it is usually possible to de-escalate the therapy, ${ }^{92,93}$ and such an approach reduces mortality in patients with VAP compared to those in whom therapy is not de-escalated.92-95 Despite timely initiation of appropriate antibiotic therapy and other supportive measures, VAP continues to be associated with significant mortality. ${ }^{1,15,92}$ Therefore, alternative methods of treatment, including the addition of inhaled antimicrobials, are being explored to try and reduce VAP-associated morbidity and mortality.

The use of inhaled antimicrobials in patients with VAP has been extensively reviewed in recent years. ${ }^{4,5,96-98}$ The consensus of opinion is that inhaled antimicrobials should only be employed as an adjunct to systemic antibiotic therapy; only a few RCT have evaluated the use of inhaled antibiotics, and their role in treatment of VAP remains inconclusive. ${ }^{4,5,96-98}$ Some recent studies lend support to the use of inhaled antimicrobials for VAP. Czosnowski and coworkers administered inhaled and parenteral antibiotics for the treatment of VAP. ${ }^{99}$ In patients with bacteriologically confirmed VAP, there were 45 episodes of Pseudomonas aeruginosa infection; 14 with Acinetobacter baumannii; and one with both organisms. Clinical success was achieved in $>70 \%$ of infections, including those due to MDR organisms. ${ }^{99}$ Likewise, inhaled aminoglycosides administered to cancer patients with Gramnegative VAP provided greater clinical and microbiological success compared to a group receiving intravenous antibiotics alone. ${ }^{100}$ A double blind, placebo-controlled study in ventilator-dependent patients with Gramnegative VAP found that when patients were given adjunctive inhaled amikacin $400 \mathrm{mg}$ twice 
daily with the PDDS delivery system in addition to systemic antibiotics, the requirement for systemic antibiotics on day 7 was reduced to one-half of that in patients receiving placebo inhalations. ${ }^{101}$ Thus, addition of inhaled antibiotics may reduce the requirement for systemic antibiotics, and could help in reducing the duration of therapy.

A meta-analysis that included five RCT ${ }^{102}$ reported that administration of antimicrobials via the respiratory tract (either inhaled or endotracheally instilled) was associated with better treatment success as compared to controls, but there was no significant effect on all-cause mortality. Among the five RCT, there were only two reports where the antibiotic was administered by aerosol, whereas antibiotics were endotracheally instilled in the remaining three studies. Among the aerosolized antibiotic group, the total number of patients that were clinically evaluable was very small. This metaanalysis ${ }^{102}$ highlights the paucity of high-quality data in the published literature, and emphasizes the need for further studies to establish the role of inhaled antibiotics in patients with VAP.

The long-held view that inhaled antibiotics should not be employed as monotherapy for VAP was recently challenged by an elegant, randomized, phase 2 trial in patients with VAP caused by Pseudomonas aeruginosa. ${ }^{103}$ Patients receiving only nebulized ceftazidime and amikacin had clinical and bacteriological responses that were similar to those receiving intravenous ceftazidime and amikacin (or ciprofloxacin for three patients infected with organisms that showed intermediate resistance). The nebulized treatment was well tolerated and there was no increase in emergence of resistant organisms or the incidence of superinfection by other organisms. ${ }^{103}$ This was, however, a single-center study that included only 40 patients, and patients with severe pneumonia or extrapulmonary infection were excluded. Nevertheless, the challenging findings of $\mathrm{Lu}$ and colleagues ${ }^{103}$ strongly suggest the need for further investigating the role of monotherapy with inhaled antibiotics in a larger cohort of patients with moderately severe VAP.

\section{Treatment of VAP due to MDR Organisms}

When aerosolized antibiotics are employed in targeted, time limited protocols, they can be very effective in the management of MDR microorganisms in patients with VAP. ${ }^{46}$ In 22 surgical ICU patients with VAP, aerosolized aminoglycosides (16 patients with tobramycin and six patients with amikacin) were administered with parenteral antibiotics for VAP. The average duration of mechanical ventilation in these patients was 4.3 days; there were no renal or pulmonary complications and 19 of the 22 patients survived. ${ }^{104}$

The emergence of MDR strains of Pseudomonas aeruginosa and Acinetobacter baumannii that are associated with a very high mortality rate $\mathrm{r}^{105}$ led to the recent revival of interest in the use of colistin. ${ }^{106}$ Parenteral or inhaled colistin has been employed as the last line of defense against these organisms. Several retrospective case series have reported on the use of parenteral colistin in the treatment of pneumonia and other serious infections in patients who did not have CF. ${ }^{107-113}$ These investigators have shown a consistent clinical efficacy ( $>50 \%$ efficacy in most studies), an acceptable toxicity profile, and the lack of emergence of colistin-resistant $P$. aeruginosa and $A$. baumannii strains. Within the past 5 years, there have been at least three prospective case series where intravenous colistin has been employed for infections with Acinetobacter baumannii and Pseudomonas aeruginosa in ICU patients. ${ }^{114-116}$ The majority of infections were due to pneumonia caused by organisms 
Table 3. Treatment with inhaled colistin for infections due to multi-drug resistant Gram-negative infections.

\begin{tabular}{|c|c|c|c|c|c|c|}
\hline $\begin{array}{l}\text { First author, } \\
\text { year }{ }^{\text {ref }}\end{array}$ & Setting & $\begin{array}{l}\text { Number } \\
\text { of } \\
\text { patients }\end{array}$ & $\begin{array}{l}\text { Dose of colistin/ } \\
\text { duration }\end{array}$ & Sites of infection & Pathogen & Outcome \\
\hline Hamer, $2000^{81}$ & $\begin{array}{l}\text { Medical } \\
\text { wards }\end{array}$ & 3 & $\begin{array}{l}\text { 2-5 million IU/day } \\
\text { Mean duration } 12.6 \\
\text { days }\end{array}$ & $\begin{array}{l}\text { Pneumonia two pts } \\
\text { Tracheobronchitis } \\
\text { one pt }\end{array}$ & $\begin{array}{l}\text { Pseudomonas } \\
\text { aeruginosa }\end{array}$ & $\begin{array}{l}\text { Clinical cure } \\
\text { in all }\end{array}$ \\
\hline $\begin{array}{l}\text { Michalopoulos, } \\
2005^{117}\end{array}$ & ICU & 8 & $\begin{array}{l}1.5 \text { to } 6 \text { million IU/ } \\
\text { day }\end{array}$ & Pneumonia & $\begin{array}{l}\text { Acinetobacter } \\
\text { baumannii } 7 \\
\text { Pseudomonas } \\
\text { aeruginosa } 1\end{array}$ & $\begin{array}{l}87.5 \% \\
\text { clinical cure }\end{array}$ \\
\hline Kwa, $2005^{118}$ & $\begin{array}{l}\text { ICU, } \\
\text { medical } \\
\text { wards }\end{array}$ & 21 & $\begin{array}{l}\text { 2-4 million IU/day } \\
\text { Median duration } 14 \\
\text { days }\end{array}$ & Pneumonia & $\begin{array}{l}\text { Acinetobacter } \\
\text { baumannii } 17 \\
\text { Pseudomonas } \\
\text { aeruginosa } 4\end{array}$ & $\begin{array}{l}85.7 \% \\
\text { clinical cure }\end{array}$ \\
\hline Berlana, $2005^{119}$ & ICU & $\begin{array}{l}80,85 \\
\text { courses } \\
(71 \text { by } \\
\text { aerosol) }\end{array}$ & $\begin{array}{l}\text { Mean duration of } \\
\text { aerosol treatment } 12 \\
\text { days }\end{array}$ & $\begin{array}{l}\text { Pneumonia } \\
\text { (60 courses) }\end{array}$ & $\begin{array}{l}\text { Acinetobacter } \\
\text { baumannii } 69 \\
\text { Pseudomonas } \\
\text { aeruginosa } 11\end{array}$ & $\begin{array}{l}92 \% \text { micro- } \\
\text { biological } \\
\text { cure }\end{array}$ \\
\hline $\begin{array}{l}\text { Mataouakkil, } \\
2006^{120}\end{array}$ & $\mathrm{ICU}$ & 26 & $\begin{array}{l}1 \text { million IU } 3 \text { times/ } \\
\text { day by aerosol for } 15 \\
\text { days }\end{array}$ & $\begin{array}{l}\text { Pneumonia } 16 \text { pts } \\
\text { Bacteremia and } \\
\text { pneumonia three } \\
\text { pts }\end{array}$ & $\begin{array}{l}\text { Acinetobacter } \\
\text { baumannii in all }\end{array}$ & $\begin{array}{l}100 \% \\
\text { clinical cure }\end{array}$ \\
\hline $\begin{array}{l}\text { Michalopoulos, } \\
2008^{121}\end{array}$ & ICU & 60 & $\begin{array}{l}1 \text { million IU } 3 \text { times/ } \\
\text { day by aerosol for } 5 \text { to } \\
49 \text { (mean } 16.4 \text { ) days }+ \\
\text { i.v. colistin ( } 57 \text { pts) or } \\
\text { i.v. meropenem (three } \\
\text { pts) }\end{array}$ & Pneumonia & $\begin{array}{l}\text { Acinetobacter } \\
\text { baumannii } 37 \\
\text { Pseudomonas } \\
\text { aeruginosa } 12 \\
\text { Klebsiella } \\
\text { pneumoniae } 11\end{array}$ & $\begin{array}{l}83.3 \% \\
\text { clinical } \\
\text { and micro- } \\
\text { biologic cure }\end{array}$ \\
\hline Falagas, $2009^{122}$ & $\begin{array}{l}\text { Hospital/ } \\
\text { ICU }\end{array}$ & 5 & $\begin{array}{l}1 \text { million IU q } 8 \text { hr or } \\
0.5 \text { million IU q } 6 \mathrm{hr} \\
\text { (one pt) for } 6 \text { to } 11 \\
\text { days no i.v. colistin }\end{array}$ & $\begin{array}{l}\text { VAP three pts, NP } \\
\text { two pts }\end{array}$ & $\begin{array}{l}\text { Acinetobacter } \\
\text { baumannii } 3 \\
\text { Pseudomonas } \\
\text { aeruginosa } 1 \\
\text { Klebsiella } \\
\text { pneumoniae, } \\
\text { Acinetobacter } \\
\text { baumanniii, } \\
\text { Pseudomonas } \\
\text { aeruginosa } 1\end{array}$ & $\begin{array}{l}80 \% \text { cure } \\
\text { rate; } 1 \text { death }\end{array}$ \\
\hline
\end{tabular}

ICU=intensive care unit; IU=international units; i.v.=intravenous; $\mathrm{NP}=$ nosocomial pneumonia; pts=patients;

$\mathrm{VAP}=$ ventilator-associated pneumonia.

that were sensitive only to colistin. A favorable clinical and microbiological response was reported in all three studies with acceptable levels of nephrotoxicity. ${ }^{114-116}$
The experience with inhaled colistin as an adjunct to parenteral antibiotics for treatment of VAP caused by MDR Gramnegative microorganisms is even more limited 
than that with parenteral colistin (Table 3). Most studies have been retrospective analyses of small number of patients ${ }^{81,83,117-122}$ with pneumonia due to MDR Acinetobacter baumannii or Pseudomonas aeruginosa. Despite the serious nature of these infections, administration of inhaled colistin in addition to systemic antibiotic therapy (including parenteral colistin) provided encouraging results, with clinical and microbiological success in the majority of treated patients (Table 3). Significantly, colistinresistant isolates were not reported in these studies, even among patients with persistently positive cultures for Pseudomonas aeruginosa or Acinetobacter baumannii. Falagas and coworkers $^{122}$ reported an $80 \%$ success rate with inhaled colistin alone, without concomitant intravenous colistin, in patients with VAP $(n=3)$ and nosocomial pneumonia $(n=2)$ caused by MDR Gram-negative organisms. Thus, inhaled colistin could be employed in critically ill patients with MDR Gram-negative pneumonia provided that recommended dosages are used, renal function is closely monitored, and other potentially nephrotoxic agents are avoided.

In patients with nosocomial pneumonia (most caused by MDR Pseudomonas aeruginosa), who were failing intravenous therapy, improvement or cure in the vast majority (93\%) of patients was noted with the use of inhaled polymyxin B. ${ }^{83}$ Moreover, all five patients with tracheobronchitis showed improvement or were cured following inhaled polymyxin B alone, without systemic antibiotics. ${ }^{83}$ The authors concluded that inhaled polymyxin B could be considered as a salvage therapy for patients with nosocomial pneumonia or tracheobronchitis caused by MDR Gram-negative bacilli who are failing intravenous antibiotic treatment. ${ }^{83}$

Thus, there is an increasing interest in use of aerosolized antibiotics for treating patients with VAP. Further research is needed to determine the optimum methods of drug delivery, appropriate dosages, and frequency of drug administration. ${ }^{123}$

\section{Duration of Treatment}

The duration of inhaled antibiotic therapy in the published studies varied from 7 to 14 days or longer. However, there is no conclusive information on the optimal duration of therapy. In view of recent data showing that therapy of VAP with systemic antibiotics could be shortened ${ }^{124,125}$ without compromising patient outcomes, it may be possible to limit inhaled antibiotic therapy to a course of 7 to 8 days. Lu and colleagues achieved treatment success in $70 \%$ of patients receiving nebulized amikacin and ceftazidime (15 mg.kg- $\left.{ }^{1} .3 \mathrm{~h}^{-1}\right)$ for 3 days and mean $4.9 \pm$ (1SD) 1.2 days, respectively. ${ }^{103}$

\section{DISADVANTAGES OF INHALED ANTIBIOTICS}

Adverse effects due to inhaled antibiotics may be due to local irritant effects on the airways or due to toxicity of the systemically absorbed drug. ${ }^{4}$ The local effects are mainly related to cough and bronchospasm, which can be reduced by use of appropriate preservative-free formulations designed for inhalation, and pre-treatment with beta-agonist bronchodilators. ${ }^{4}$ Systemic absorption of aminoglycosides can produce renal toxicity, and appropriate dosing adjustments are needed in patients with renal failure who receive inhaled aminoglycosides. ${ }^{126,127}$ In mechanically-ventilated patients with Gramnegative pneumonia and acute renal failure who were receiving inhaled amikacin twice daily, continuous veno-venous hemodiafiltration was effective at maintaining serum trough concentrations within acceptable limits and serious adverse events were not reported. ${ }^{126}$ Single doses of inhaled amikacin are well 
tolerated in patients with chronic kidney disease and dialysis is effective in clearing the drug from the circulation in patients with end stage renal disease. ${ }^{127}$ Similarly, colistin inhalation carries the risk of nephrotoxicity and neurotoxicity. ${ }^{128}$ Colistin should be mixed with diluent immediately before use because it can be hydrolyzed to a toxic metabolite which can cause direct lung injury and lead to acute respiratory distress syndrome (ARDS). ${ }^{129}$ In clinical studies, toxic effects to inhaled antibiotics are infrequent, and the drugs needed to be discontinued because of adverse effects in a very small proportion of patients. The indiscriminate use of inhaled antibiotics could lead to emergence of drug resistant organisms. ${ }^{130}$ Thus, inhaled antibiotics should only be employed in targeted, time-limited protocols.

\section{CONCLUSION}

The potential role of inhaled antibiotics for the treatment of VAP is recognized by international guidelines. Aerosolized antibiotics used as an adjunct to systemic antibiotic therapy have shown beneficial effects for management of VAP, ${ }^{99,102}$ including VAP caused by MDR pathogens where systemic therapy alone is ineffective. The routine use of aerosolized antibiotics cannot be recommended for VAP treatment; however, in situations where systemic therapy alone is failing, when systemic therapy is denied by patients, intravenous access is not available or concerns of systemic toxicity exist, the option of nebulized antibiotics should be considered. When used in management of VAT, inhaled antibiotics reduce the frequency of VAP and facilitate weaning, but a reduction in mortality has not been observed. ${ }^{8,10,28}$ With the availability of newer generation nebulizers, that consistently deliver drugs to the lower respiratory tract with a high efficiency, and antibiotic formulations that are specifically designed for inhalation, future prospective, randomized, placebo-controlled trials will help to further establish the role of inhaled antibiotics for treatment of VAT and VAP.

\section{ACKNOWLEDGMENTS}

Dr. Dhand is the guarantor for this article, and takes responsibility for the integrity of the work as a whole. No funding or sponsorship was received for this paper. The authors have disclosed no conflicts of interest

Open Access. This article is distributed under the terms of the Creative Commons Attribution Noncommercial License which permits any noncommercial use, distribution, and reproduction in any medium, provided the original author(s) and source are credited.

\section{REFERENCES:}

1. Niederman MS, Craven DE. Guidelines for the management of adults with hospital-acquired, ventilator-associated, and healthcare-associated pneumonia. Am J Respir Crit Care Med. 2005;171:388-416.

2. Heyland DK, Cook DJ, Griffith L, Keenan SP, BrunBuisson C, Canadian Critical Trials Group. The attributable morbidity and mortality of ventilatorassociated pneumonia in the critically ill patient. Am J Respir Crit Care Med. 1999;159:1249-1256.

3. Rello J, Ollendorf DA, Oster G, et al. Epidemiology and outcomes of ventilator-associated pneumonia in a large US database. Chest. 2002;122:2115-2121.

4. Dhand R. The role of aerosolized antimicrobials in the treatment of ventilator-associated pnemonia. Respir Care. 2007;52:866-884.

5. Luyt CE, Combes A, Nieszkowska A, Trouillet JL, Chastre J. Aerosolized antibiotics to treat ventilator-associated pneumonia. Curr Opin Infect Dis. 2009;22:154-158. 
6. Craven DE, Hjalmarson KI. Ventilator-associated tracheobronchitis and pneumonia: thinking outside the box. Clinical Infectious Diseases. 2010;51(S1):S59-S66.

7. Nseir S, Di Pompeo C, Pronnier P, et al. Nosocomial tracheobronchitis in mechanically ventilated patients: incidence, aetiology and outcome. Eur Respir J. 2002;20:1483-1489.

8. Dallas J, Skrpky L, Abebe N, Boyle WA III, Kollef $\mathrm{MH}$. Ventilator-associated tracheobronchitis (VAT) in a mixed surgical and medical ICU population. Chest. 2011;139:513-518. Epub.

9. A'Court $\mathrm{CH}$, Garrard CS, Crook D, et al. Microbiologic lung surveillance in mechanically ventilated patients, using non-directed bronchial lavage and quantitative culture. QJ Med. 1993;86:635-648.

10. Nseir S, Ader F, Marquette CH. Nosocomial tracheobronchitis. Curr Opin Infect Dis. 2009;22:148-153.

11. Horan TC, Andrus M, Dudeck MA. CDC/NHSN surveillance definition of health care-associated infection and criteria for specific types of infections in the acute care setting. Am J Infect Control. 2008;36:309-332.

12. Malacarne $P$, Langer $M$, Nascimben $E$, et al. Building a continuous multicenter infection surveillance system in the intensive care unit: findings from the initial data set of 9493 patients from 71 Italian intensive care units. Crit Care Med. 2008;36:1105-1113.

13. Kampf G, Wischnewski N, Schulgen G, et al. Prevalence and risk factors for nosocomial lower respiratory tract infections in German hospitals. J Clin Epidemiol. 1998;51:495-502.

14. Agrafiotis M, Siempos II, Falagas ME. Frequency, prevention, outcome and treatment of ventilatorassociated tracheobronchitis: systematic review and meta-analysis. Respir Med. 2010;104:325-336.

15. Chastre J, Fagon JY. Ventilator-associated pneumonia. Am J Respir Crit Care Med. 2002;165:867-903.

16. Fridkin SK. Increasing prevalence of antimicrobial resistance in intensive care units. Crit Care Med. 2001;29(suppl. 4):N64-N68.

17. Obritsch MD, Fish DN, MacLaren R, Jung R. National surveillance of antimicrobial resistance in Pseudomonas aeruginosa isolates obtained from intensive care unit patients from 1993 to 2002. Antimicrob Agents Chemotherap. 2004;48:46064610 .
18. Klevens RM, Edwards JR, Tenover FC, McDonald LC, Horan T, Gaynes R. National Nosocomial Infections Surveillance System. Changes in the epidemiology of methicillin-resistant Staphylococcus aureus in intensive care units in US hospitals, 1992-2003. Clinical Infectious Diseases. 2006;42:389-391. Epub.

19. Ibrahim EH, Ward S, Sherman G, Kollef MH. A comparative analysis of patients with early-onset vs late-onset nosocomial pneumonia in the ICU setting. Chest. 2000;117:1434-1442.

20. Carratala J, Mykietiuk A, Fernandez-Sabe N, et al. Health care-associated pneumonia requiring hospital admission: epidemiology, antibiotic therapy, and clinical outcomes. Arch Intern Med. 2007;167:1393-1399.

21. Michel F, Franceschini B, Berger $P$, et al. Early antibiotic treatment for BAL-confirmed ventilator-associated pneumonia: a role for routine endotracheal aspirate cultures. Chest. 2005; 127:589-597.

22. Depuydt P, Benoidt D, Vogelaers D, et al. Systemic surveillance cultures as a tool to predict involvement of multidrug antibiotic resistant bacteria in ventilator-associated pneumonia. Intensive Care Medicine. 2008;34:675-682.

23. Yang KZH, Guglielmo BJ, Wiener-Kronish J. Multidrug-resistant Pseudomonas aeruginosa ventilator-associated pneumonia: the role of endotracheal aspirate surveillance cultures. Ann Pharmacother. 2009;43:28-35.

24. Hayon J, Figliolini C, Combes A, et al. Role of serial routine microbiologic culture results in the initial management of ventilator-associated pneumonia. Am J Respir Crit Care Med. 2002;165:41-46.

25. Rouby JJ, Martin De Lassale E, Poete P, et al. Nosocomial bronchopneumonia in the critically ill. Histologic and bacteriologic aspects. Am Rev Respir Dis. 1992;146:1059-1066.

26. Honeybourne D, Baldwin DR. The site concentrations of antimicrobial agents in the lung. J Antimicrobial Chemotherap. 1992;30:249-260.

27. Wilkinson TM, Patel IS, Wilks M, Donaldson GC, Wedzicha JA. Airway bacterial load and FEV1 decline in patients with chronic obstructive pulmonary disease. Am J Respir Crit Care Med. 2003;167:1090-1095.

28. Palmer LB, Smaldone GC, Chen JJ, et al. Aerosolized antibiotics and ventilator-associated tracheobronchitis in the intensive care unit. Crit Care Med. 2008;36:2008-2013. 
29. Miller DD, Amin MM, Palmer LB, et al. Aerosol delivery and modern mechanical ventilation: in vitro/in vivo evaluation. Am J Respir Crit Care Med. 2003;168:1205-1209.

30. Weibel ER, Gil J. Structure-function relationships at the alveolar level. In West JB, ed. Bioengineering aspects of the lung. New York: Marcel Dekker, 1977.

31. Niederman MS. Principles of antibiotic use and the selection of empiric therapy for pneumonia. In Fishman's Pulmonary Diseases and Disorders. Fishman AP, Elias JA, Fishman JA, Grippi MA, Kaiser LR, Senior RM, eds. McGraw Hill, New York, 3rd ed; 1998. Chap 122; pp 1939-1949.

32. Stachelin LA. Structure and function of intercellular junctions. Int Rev Cytol. 1974;39:191-283.

33. Baldwin DR, Honeybourne D, Wise R. Pulmonary disposition of antimicrobial agents: methodological considerations. Antimicrob Agents Chemotherap. 1992;36:1171-1175.

34. Levy J, Smith AL, Kenny MA, Ramsey B, Schoenknecht FD. Bioactivity of gentamicin in purulent sputum from patients with cystic fibrosis or bronchiectasis: comparison with activity in serum. J Infectious Diseases. 1983;148:1069-1076.

35. Mendelman PM, Smith AL, Levy J, et al. Aminoglycoside penetration, inactivation, and efficacy in cystic fibrosis sputum. Am Rev Respir Dis. $1985 ; 132: 761-765$.

36. Valcke $\mathrm{Y}$, Pauwels $\mathrm{R}$, Van der Straeten M. Pharmacokinetics of antibiotics in the lungs. Eur Respir J. 1990;3:715-722.

37. McCullagh A, Rosenthal M, Wanner A, Hurtado A, Padley S, Bush A. The bronchial circulation - worth a closer look. Pediatr Pulmonol. 2010;45:1-13.

38. Ilowite JS, Gorvoy JD, Smaldone GC. Quantitative deposition of aerosolized gentamicin in cystic fibrosis. Am Rev Respir Dis. 1987;136:1445-1449.

39. Bergogne-Bérézin E. Pharmacokinetics of antibiotics in cystic fibrosis patients with particular reference to the bronchopulmonary tree. Infection. 1987;15:288-294.

40. LeConte P, Potel G, Peltier P, et al. Lung distribution and pharmacokinetics of aerosolized tobramycin. Am Rev Respir Dis. 1993;147:1279-1282.

41. Dhand R. Aerosol delivery during mechanical ventilation: from basic techniques to new devices. J Aerosol Med Pulm Drug Deliv. 2008;21:45-60.
42. Dhand R, Guntur VP. How best to deliver aerosol medications to mechanically-ventilated patients. Clin Chest Med. 2008;29:277-296.

43. O'Doherty MJ, Thomas SH, Page CJ, et al. Delivery of a nebulized aerosol to a lung model during mechanical ventilation. Effect of ventilator settings and nebulizer type, position, and volume of fill. Am Rev Respir Dis. 1992;146:383-388.

44. O'Riordan TG, Greco MJ, Perry RJ, et al. Nebulizer function during mechanical ventilation. Am Rev Respir Dis. 1992;145:1117-1122.

45. O'Riordan TG, Palmer LB, Smaldone GC. Aerosol deposition in mechanically ventilated patients. Optimizing nebulizer delivery. Am J Respir Crit Care Med. 1994;149:214-219.

46. Palmer LB. Aerosolized antibiotics in critically ill ventilated patients. Curr Opin Crit Care. 2009;15:413-418.

47. Palmer LB, Smaldone GC, Simon SR, O'Riordan TG, Cuccia A. Aerosolized antibiotics in mechanically ventilated patients: delivery and response. Crit Care Med. 1998;26:31-39.

48. Dhand R. Nebulizers that use a vibrating mesh or plate with multiple apertures to generate aerosol. Respir Care. 2002;47:1406-1416; discussion 14161418.

49. Pedersen KM, Handlos VN, Heslet L, Kristensen HG. Factors influencing the in vitro deposition of tobramycin aerosol: a comparison of an ultrasonic nebulizer and a high-frequency vibrating mesh nebulizer. J Aerosol Med. 2006;19:175-183.

50. Ehrmann S, Mercier E, Vecellio L, et al. Pharmacokinetics of high-dose nebulized amikacin in mechanically-ventilated healthy subjects. Intensive Care Medicine. 2008;34:755-762.

51. Dhand R, Sohal H. Pulmonary Drug Delivery System for inhalation therapy in mechanicallyventilated subjects. Expert Rev Med Devices. 2008;5:9-18.

52. Luyt CE, Clavel M, Guntupalli $\mathrm{K}$, et al. Pharmacokinetics and lung delivery of PDDSaerosolized amikacin (NKTR-061) in intubated and mechanically ventilated patients with nosocomial pneumonia. Critical Care. 2009;13;R200. Epub.

53. Zarilli GM, Monteforte M, Baram D, et al. Systemic versus aerosolized delivery of vancomycin for MRSA: concentrations in lungs and serum [abstract]. Am J Respir Crit Care Med. 2008;177:A286. 
54. Geller DE, Flume P, Griffith DC. Pharmacokinetics and safety of MP-376 (levofloxacin inhalation solution) in cystic fibrosis subjects. Antimicrob Agents Chemotherap. 2011;55:2636-2640.

55. King $\mathrm{P}$, Lomovskaya O, Griffith DC, et al. In vitro pharmacodynamics of levofloxacin and other aerosolized antibiotics under multiple conditions relevant to chronic pulmonary infection in cystic fibrosis. Antimicrob Agents Chemotherap. 2010;54:143-148.

56. King P, Citron DM, Griffith DC, Lomovskaya $\mathrm{O}$, Dudley MN. Effect of oxygen limitation on the in vitro activity of levofloxacin and other antibiotics administered by the aerosol route against Pseudomonas aeruginosa from cystic fibrosis patients. Diagn Microbiol Infect Dis. 2010;66:181-186.

57. Inglis TJ, Millar MR, Jones JG, Robinson DA. Tracheal tube biofilm as a source of bacterial colonization of the lung. J Clin Microbiol. 1989;27:2014-2018.

58. Prince AS. Biofilms, antimicrobial resistance, and airway infection. N Engl J Med. 2002;347:1110-1111.

59. Shah C, Kollef MH. Endotracheal tube intraluminal volume loss among mechanically ventilated patients. Crit Care Med. 2004;32:120-125.

60. Adair CG, Gorman SP, Feron BM, et al. Implications of endotracheal tube biofilm for ventilatorassociated pneumonia. Intensive Care Medicine. 1999;25:1072-1076.

61. Gorman SP, McGovern JG, Woolfson AD, Adair CG, Jones DS. The concomitant development of poly(vinyl chloride)-related biofilm and antimicrobial resistance in relation to ventilatorassociated pneumonia. Biomaterials 2001;22:27412747.

62. Bauer TT, Torres A, Ferrer R, Heyer CM, SchultzeWerninghaus G, Rasche K. Biofilm formation in endotracheal tubes. Association between pneumonia and the persistence of pathogens. Monaldi Arch Chest Dis. 2002;57:84-87.

63. Mah TF, Pitts B, Pellock B, Walker GC, Stewart PS, O'Toole GA. A genetic basis for Pseudomonas aeruginosa biofilm antibiotic resistance. Nature. 2003;426:306-310.

64. Favre-Bonte S, Chamot E, Kohler T, Romand JA, van Delden C. Autoinducer production and quorum-sensing dependent phenotypes of Pseudomonas aeruginosa vary according to isolation site during colonization of intubated patients. BMC Microbiol. 2007; 7:33.
65. Greenberg EP. Bacterial communication: tiny teamwork. Nature. 2003;424:134.

66. Le Berre R, Nguyen S, Nowak E, et al. Quorumsensing activity and related virulence factor expression in clinically pathogenic isolates of Pseudomonas aeruginosa. Clin Microbiol Infect. 2008;14:337-43. Epub.

67. Sadikot RT, Blackwell TS, Christman JW, Prince AS. Pathogen-host interactions in Pseudomonas aeruginosa pneumonia. Am J Respir Crit Care Med. 2005;171:1209-1223. Epub.

68. Latifi A, Foglino M, Tanaka K, Williams P, Lazdunski A. A hierarchical quorum-sensing cascade in Pseudomonas aeruginosa links the transcriptional activators LasR and RhIR (VsmR) to expression of the stationary-phase sigma factor RpoS. Mol Microbiol. 1996;21:1137-1146.

69. Dénervaud V, TuQuoc P, Blanc D, et al. Characterization of cell-to-cell signaling-deficient Pseudomonas aeruginosa strains colonizing intubated patients. J Clin Microbiol. 2004;42:554-562.

70. Kohler T, Guanella R, Carlet J, van Delden C. Quorum sensing dependent virulence during Pseudomonas aeruginosa colonization and pneumonia in mechanically ventilated patients. Thorax. 2010;65:703-710.

71. Njoroge J, Sperandio V. Jamming bacterial communication: new approaches for the treatment of infectious diseases. EMBO Mol Med. 2009;1:201-210.

72. Zhuo $\mathrm{H}$, Yang $\mathrm{K}$, Lynch $\mathrm{SV}$, et al. Increased mortality of ventilated patients with endotracheal Pseudomonas aeruginosa without clinical signs of infection. Crit Care Med. 2008;36:2495-2503.

73. Matsushima A, Tasaki O, Shimizu $\mathrm{K}$, et al. Preemptive antibiotic treatment based on Gram staining reduced the incidence of ARDS in mechanically ventilated patients. J Trauma. 2008;65:309-315.

74. Marr AK, Overhage J, Bains M. The Lon protease of Pseudomonas aeruginosa is induced by aminoglycosides and is involved in biofilm formation and motility. Microbiology. 2007; 153:474-482.

75. Adair CG, Gorman SP, Byers LM, et al. Eradication of endotracheal biofilm by nebulized gentamicin. Intensive Care Medicine. 2002;28:426-431.

76. Kollef MH, Afessa B, Anzueto A et al. Silver-coated endotracheal tubes and incidence of ventilatorassociated pneumonia: the NASCENT randomized trial. JAMA. 2008;300;805-813. 
77. Raad II, Mohamed JA, Reitzel RA, et al. The prevention of biofilm colonization by multidrugresistant pathogens that cause ventilator-associated pneumonia with antimicrobial-coated endotracheal tubes. Biomaterials. 2011;32:2689-2694.

78. Le J, Ashley ED, Neuhauser MM, et al. Consensus summary of aerosolized antimicrobial agents: application of guideline criteria. Pharmacotherapy. 2010;30:562-584.

79. Geller DE, Flume PA, Staab D, et al. Levofloxacin Inhalation Solution (MP-376) in patients with cystic fibrosis with Pseudomonas aeruginosa. Am J Respir Crit Care Med. 2011;183:1510-1516. Epub.

80. Torres A, Valencia M. Does ventilator-associated tracheobronchitis need antibiotic treatment? Critical Care. 2005;9:255-256. Epub.

81. Hamer DH. Treatment of nosocomial pneumonia and tracheobronchitis caused by multidrug-resistant Pseudomonas aeruginosa with aerosolized colistin. Am J Respir Crit Care Med. 2000;162:328-330.

82. Ahmed QA, Niederman MS. Respiratory infection in the chronically critically ill patient. Ventilatorassociated pneumonia and tracheobronchitis. Clin Chest Med. 2001;22:71-85.

83. Pereira GH, Muller PR, Levin AS. Salvage treatment of pneumonia and initial treatment of tracheobronchitis caused by multidrug-resistant Gram-negative bacilli with inhaled polymyxin B. Diagn Microbiol Infect Dis. 2007;58:235-240.

84. Nseir S, DiPompeo C, Soubrier S, et al. Outcomes of ventilated COPD patients with nosocomial tracheobronchitis: a case control study. Infection. 2004;32:210-216.

85. Nseir S, DiPompeo C, Soubrier S, et al. Effect of ventilator-associated tracheobronchitis on outcome in patients without chronic respiratory failure: a case control study. Critical Care. 2005;9:R238-R245.

86. Nsier S, Favory R, Josefowicz E, et al. Antimicrobial treatment for ventilator-associated tracheobronchitis: a randomized, controlled, multicenter study. Critical Care. 2008;12:R62.

87. Cunha BA. Aerosolized antibiotics are not a good idea-don't go with the flow: Premum Non Nocere! Crit Care Med. 2009;37:799-800; author reply 800-801.

88. Rello J. Bench-to-bedside review: Therapeutic options and issues in the management of ventilator-associated bacterial pneumonia. Critical Care. 2005;9:259-265.
89. Kollef $\mathrm{MH}$. Inadequate antimicrobial treatment: an important determinant of outcome of hospitalized patients. Clinical Infectious Diseases. 2000;31;S131-S138.

90. Ibrahim EH, Sherman G, Ward S, Fraser VJ, Kollef $\mathrm{MH}$. The influence of inadequate antimicrobial treatment of bloodstream infections on patient outcomes in the ICU setting. Chest. 2000;118:146-155.

91. Cosgrove SE, Kaye KS, Elipoulous GM, Carmeli Y. Health and economic outcomes of the emergence of third-generation cephalosporin resistance in Enterobacter species. Arch Intern Med. 2002;162:185-190.

92. Kollef MH, Morrow LE, Niederman MS, et al. Clinical characteristics and treatment patterns among patients with ventilator-associated pneumonia. Chest. 2006;129:1210-1218.

93. Soo Hoo GW, Wen YE, Nguyen TV, Goetz MB. Impact of clinical guidelines in the management of severe hospital-acquired pneumonia. Chest. 2005;128:2778-2787.

94. Schlueter M, James C, Dominguez A, et al. Practice patterns for antibiotic de-escalation in culturenegative healthcare-associated pneumonia. Infection. 2010;38:357-362.

95. Masterton RG. Antibiotic de-escalation. Crit Care Clin. 2011;27:149-162.

96. Klepser ME. Role of nebulized antibiotics for the treatment of respiratory infections. Curr Opin Infect Dis. 2004;17:109-112.

97. Lesho E. Role of inhaled antibacterials in hospital acquired and ventilator-associated pneumonia. Expert Rev Anti Infect Ther. 2005;3:445-451.

98. Hagerman JK, Hancock KE, Klepser ME. Aerosolised antibiotics: A critical appraisal of their use. Expert Opin Drug Delivery. 2006;3:71-86.

99. Czosnowski QA, Wood GC, Magnotti LJ, et al. Adjunctive aerosolized antibiotics for treatment of ventilator-associated pneumonia. Pharmacotherapy. 2009;29:1054-1060.

100. Ghannam DE, Rodriguez DH, Raad II, Safdar A. Inhaled aminoglycosides in cancer patients with ventilator-associated Gram-negative bacterial pneumonia: safety and feasibility in the era of escalating drug resistance. Eur J Clin Microbiol Infect Dis. 2009;28:253-259.

101. Niederman MS, Chastre J, Corkery K, et al. Inhaled amikacin reduces IV antibiotic use in intubated mechanically ventilated patients (abstract). Am J Respir Crit Care Med. 2007;175:A326. 
102. Ioannidou E, Siempos II, Falagas ME. Administration of antimicrobials via the respiratory tract for the treatment of patients with nosocomial pneumonia. J Antimicrob Chemotherap. 2007;60:1216-1226.

103. Lu Q, Yang J, Liu Z, et al. Nebulized ceftazidime and amikacin in ventilator-associated pneumonia caused by Pseudomonas aeruginosa. Am J Respir Crit Care Med. 2011;184:106-115. Epub 2011.

104. Mohr AM, Sifri ZC, Horng HS, et al. Use of aerosolized aminoglycosides in the treatment of Gram-negative ventilator-associated pneumonia. Surg Infect (Larchmt). 2007;8:349-357.

105. Fagon JY, Chastre J, Hance AJ, Montravers P, Novara A, Gibert C. Nosocomial pneumonia in ventilated patients: a cohort study evaluating attributable mortality and hospital stay. Am J Med. 1993;94:281-288.

106. Falagas ME, Kasiakou SK, Tsiordas S, Michalopoulos A. The use of intravenous and aerosolized polymyxins for the treatment of infections in critically ill patients: a review of the recent literature. CM \&R. 2006;4:138-146.

107. Levin AS, Barone AA, Penco J, et al. Intravenous colistin as therapy for nosocomial infections caused by multidrug-resistant Pseudomonas aeruginosa and Acinetobacter baumannii. Clinical Infectious Diseases. 1999;28:1008-1011.

108. Garnacho-Montero J, Ortiz-Leyba C, JimenezJimenez FJ, et al. Treatment of multidrug-resistant Acinetobacter baumannii ventilator-associated pneumonia (VAP) with intravenous colistin: a comparison with imipenem-susceptible VAP. Clinical Infectious Diseases. 2003;36:1111-1118.

109. Linden PK, Kusne S, Coley $K$, et al. Use of parenteral colistin for the treatment of sepsis from multi resistant gram-negative bacilli in critically ill patients. Critical Care. 2003;37:e154-e160.

110. Markou N, Apostolakos H, Koumoudiou C, et al. Intravenous colistin in the treatment of sepsis from multiresistant gram-negative bacilli in critically ill patients. Critical Care. 2003;7:R78-R83.

111. Kasiakou SK, Michalopoulos A, Soteriades ES, et al. Combination therapy with intravenous colistin for management of infections due to multidrug-resistant Gram-negative bacteria in patients without cystic fibrosis. Antimicrob Agents Chemotherap. 2005;49:3136-3146.

112. Montero M, Horcajada JP, Sorli L, et al. Effectiveness and safety of colistin for the treatment of multidrug-resistant Pseudomonas aeruginosa infections. Infection. 2009;37:461-465.
113. Gounden R, Bamford C, van Zyl-Smit R, Cohen K, Maartens G. Safety and effectiveness of colistin compared with tobramycin for multi-drug resistant Acinetobacter baumannii infections. BMC Infectious Diseases. 2009;9:26.

114. Reina R, Estenssoro E, Saenz G, et al. Safety and efficacy of colistin in Acinetobacter and Pseudomonas infections. Intensive Care Medicine. 2005;31:1058-1065.

115. Kallel H, Bahloul M, Hergafi L, et al. Colistin as salvage therapy for nosocomial infections caused by multidrug-resistant bacteria in the ICU. International Journal of Antimicrobial Agents. 2006;28:366-369.

116. Koomanachai P, Tiengrim S, Kiratisin P, Thamlikitkul V. Efficacy and safety of colistin (colistimethate sodium) for therapy of infections caused by multidrug-resistant Pseudomonas aeruginosa and Acinetobacter baumannii in Sriraj Hospital, Bangkok, Thailand. Int Journal of Infectious Diseases. 2007;11:402-406.

117. Michalapoulos A, Kastakou SK, Mastora Z, et al. Aerosolized colistin for the treatment of nosocomial pneumonia due to multidrug-resistant Gram-negative bacteria in patients without cystic fibrosis. Critical Care. 2005;9:R53-R59.

118. Kwa AL, Loh C, Low JG, Kurup A, Tam VH. Nebulized colistin in the treatment of pneumonia due to multidrug-resistant Acinetobacter baumannii and Pseudomonas aeruginosa. Clinical Infectious Diseases. 2005;41:754-757.

119. Berlana D, Llop JM, Fort E, Badia MB, Jodar R. Use of colistin in the treatment of multiple-drugresistant gram-negative infections. Am J Health Syst Pharm. 2005;62:39-47.

120. Mataouakkil S, Charra B, Hachimi A, et al. Colistin and rifampicin in the treatment of nosocomial infections from multiresistant Acinetobacter baumannii. J Infect. 2006;53:274-278.

121. Michalopoulos A, Fotakis D, Virtzili S, et al. Aerosolized colistin as adjunctive treatment of ventilator-associated pneumonia due to multidrugresistant Gram-negative bacteria: a prospective study. Respir Med. 2008;102:407-412.

122. Falagas ME, Siempos II, Rafailidis PI, et al. Inhaled colistin as monotherapy for multidrug-resistant gram (-) nosocomial pneumonia: a case series. Respir Med. 2009;103:707-713.

123. Michalopoulos A, Metaxas E, Falagas M. Aerosol delivery of antimicrobial Agents during mechanical ventilation: current practice and perspectives. Current Drug Delivery. 2011;8:208-212. 
124. Singh N, Rogers P, Atwood CW, et al. Short course empiric antibiotic therapy for patients with pulmonary infiltrates in the intensive care unit. A proposed solution for indiscriminate antibiotic prescription. Am J Respir Crit Care Med. 2000;162:505-511.

125. Chastre J, Wolff M, Fagon JY, et al. Comparison of 8 vs 15 days of antibiotic therapy for ventilatorassociated pneumonia in adults: a randomized trial. JAMA. 2003;290:2588-2598.

126. Luyt CE, Eldon MA, Stass H, Gribben D, Corkery $\mathrm{K}$, Chastre J. Pharmacokinetics and tolerability of amikacin administered as BAY41-6551 aerosol in mechanically ventilated patients with Gramnegative pneumonia and acute renal failure. J Aerosol Med Pulm Drug Deliv. 2011;24.
127. Stass H, Corkery K, Gribben D, Eldon MA. Pharmacokinetics and tolerability of BAY41-6551 in subjects with chronic kidney disease. J Aerosol Med Pulm Drug Deliv. 2011;24.

128. Linden PK, Paterson DL. Parenteral and inhaled colistin for treatment of ventilator-associated pneumonia. Clinical Infectious Diseases. 2006;43:S89-S94.

129. McCoy KS. Compounded colistimethate as possible cause of fatal acute respiratory distress syndrome. N Engl J Med. 2007;357:2310-2311.

130. Feeley TW, Du Moulin GC, Hedley-Whyte J et al. Aerosol polymyxin and pneumonia in seriously ill patients. N Engl J Med. 1975,293:471-475. 